\title{
ANALISIS BEBAN KERJA OPERATOR BAGIAN BOILER DENGAN LINGKUNGAN KERJA FISIK DI PT. PERKEBUNAN NUSANTARA III PKS SISUMUT
}

\author{
Syarifuddin ${ }^{1 *}$, Ayrianti Melinda Pane ${ }^{1}$ dan Muzakir ${ }^{2}$ \\ 1Jurusan Teknik Industri, Fakultas Teknik, Universitas Malikussaleh, Aceh Utara, Indonesia \\ 2Jurusan Teknik Industri, Fakultas Teknik, Universitas Teuku Umar, Aceh Barat, Indonesia \\ *Corresponding Author: syarifuddin@unimal.ac.id
}

\begin{abstract}
Abstrak - Beban kerja merupakan beban yang diterima oleh pekerja akibat pelaksanaan kerja, yang mana beban kerja ini diterima oleh tubuh akibat melaksanakan suatu aktivitas kerja. Stasiun boiler merupakan salah satu stasiun yang ada di PT Perkebunan Nusantara III PKS Sisumut. Ketel uap (boiler) digunakan sebagai sumber tenaga dan sumber uap yang akan dipakai untuk mengolah kelapa sawit.. Stasiun boiler mempunyai suhu ruangan sebesar $29-42^{\circ} \mathrm{C}$ akibat dipengaruhi oleh paparan panas dari tungku pembakaran boiler. Operator bekerja selama 8 jam kerja per hari dan berada di lingkungan kerja yang panas. Melalui pengukuran beban kerja, maka akan diketahui apakah kerja beban kerja seorang operator sudah optimal dengan adanya pengaruh temperatur disekitar lingkungan. Beban kerja yang diperoleh dari perhitungan komsumsi energi didapat hasil nilai rata-rata $\mathrm{E}=8,031 \mathrm{Kkal} /$ menit dan nilai rata-rata $\% \mathrm{CVL}=60,39$ (kerja dalam waktu singkat) dikategorikan bahwa beban kerja operator merupakan beban kerja berat yang berarti operator tidak diperbolehkan beraktivitas dalam waktu yang lama. Dan temperatur yang diperoleh dari perhitungan rata-rata nilai ISBB pada stasiun boiler adalah $33,5^{\circ} \mathrm{C}$. Hal ini menunjukkan bahwa iklim kerja di stasiun boiler melebihi NAB. Dengan demikian, temperatur pada lingkungan kerja merupakan salah satu penyebab terjadinya kelelahan operator boiler saat bekerja. Berdasarkan persamaan regresi antara denyut nadi kerja dan temperatur diperoleh nilai korelasi 1,000. Hal ini menunjukkan bahwa denyut nadi kerja mempunyai hubungan antara denyut nadi kerja dengan temperatur. Semakin tinggi temperatur maka denyut nadi juga akan semakin cepat.
\end{abstract}

Kata Kunci: Beban Kerja, Temperature, Operator, Boiler.

\section{Pendahuluan}

Beban kerja fisik merupakan beban yang diterima oleh fisik operator selama pelaksanaan kerja. Lingkungan kerja adalah sesuatu yang ada disekitar para pekerja dan dapat mempengaruhi dirinya dalam menjalankan tugas yang dibebankan pada mereka. Menurut standard temperature pada area kerja industri dengan Keputusan Menteri Kesehatan RI nomor 1405/MENKES/SK/XI/2002 berada pada kisaran $18-30^{\circ} \mathrm{C}$.

Pabrik Kelapa Sawit Sisumut adalah salah satu perusahaan yang dimiliki oleh PT. Perkebunan Nusantara III yang bergerak dibidang produksi hasil perkebunan
Tandan Buah Segar (TBS) Kelapa Sawit menjadi produk Crude Palm Oil (CPO) dan Inti Sawit (Kernel).

Pabrik Kelapa Sawit Sisumut membutuhkan ketel uap (boiler) sebagai sumber tenaga dan sumber uap yang akan dipakai untuk mengolah kelapa sawit. Permasalahan beban kerja ditemukan pada stasiun boiler. Stasiun boiler mempunyai suhu ruangan sebesar $29-42^{\circ} \mathrm{C}$. Hal ini mengindikasikan lingkungan kerja stasiun boiler memiliki temperatur ruangan yang panas akibat termal di boiler dipengaruhi oleh paparan panas dari tungku pembakaran boiler. Salah satu pekerjaan yang dilakukan oleh operator boiler adalah kegiatan membersihkan abu (hasil dari sisa pembakaran cangkang dan fyber) yang ada di dalam 
tungku pembakaran boiler.

Pembersihan abu dilakukan setiap pergantian bahan bakar boiler. pembersihan abu merupakan pekerjaan bersifat fisik yang menuntut kekuatan otot dan ketelitian dari pekerjanya. Operator bekerja selama 8 jam kerja per hari dan berada di lingkungan kerja yang panas. Sehingga dapat mempengaruhi operator ditandai dengan mengeluarkan keringat yang berlebihan dan menyebabkan terlalu sering beristirahat pada saat melakukan kegiatan pembersihan abu tersebut.

Adapun tujuan dalam melakukan kerja praktik ini adalah sebagai berikut:

1. Untuk mengetahui beban kerja pada operator boiler.

2. Untuk mengetahui pengaruh antara temperatur terhadap denyut nadi pada operator boiler.

\section{Tinjauan Pustaka}

\section{Ergonomi}

Ergonomi terdiri dari dua suku kata yang berasal dari Yunani yakni Ergo dan Nomos yang masing-masing artinya adalah kerja dan hukum. Oleh karena itu ergonomi adalah salah satu disiplin ilmu yang mengkaji manusia yang berhubungan dengan aktivitas yang dilakukan manusia tersebut [1].

Ergonomi atau faktor manusia adalah disiplin ilmu yang berfokus terhadap pemahaman berdasarkan interaksi manusia dengan elemen kerja yang berada pada suatu sistem dan pekerjaan yang berdasarkan pengaplikasian dari teori, data dan metode-metode untuk merancang suatu sistem pengoptimisasian manusia [2].

\section{Kemampuan Fisik dan Beban Kerja}

Menurut [3] bahwa setiap beban kerja yang diberikan kepada manusia harus seimbang antara kemampuan fisik, kognitif, dan keterbatasannya untuk melakukan perkerjaan dengan beban kerja tersebut. Beban kerja merupakan beban yang diterima oleh pekerja akibat pelaksanaan kerja, yang mana beban kerja ini diterima oleh tubuh akibat melaksanakan suatu aktivitas kerja.

Menurut [1] [3] bahwa ada beberapa faktor yang mempengaruhi beban kerja untuk masing-masing individu terdiri dari faktor internal dan faktor eksternal.

\section{Lingkungan Kerja}

Lingkungan kerja adalah faktor-faktor diluar manusia, baik fisik mau pun non fisik dalam suatu organisasi. [4] menyatakan bahwa lingkungan kerja fisik adalah semua keadaan berbentuk fisik yang terdapat di sekitar tempat kerja yang dapat mempengaruhi karyawan baik secara langsung maupun tidak langsung. lingkungan kerja non fisik adalah semua keadaan yang terjadi yang berkaitan dengan hubungan kerja, baik hubungan dengan atasan maupun hubungan sesama rekan kerja, ataupun hubungan dengan bawahan.

\section{Denyut Nadi}

Denyut nadi adalah frekuensi irama denyut/detak jantung yang dapat dipalpasi (diraba) dipermukaan kulit pada tempat-tempat tertentu. Denyut nadi adalah getaran didalam pembuluh darah arteri akibat kontraksi ventrikel kiri jantung. Denyut nadi yang optimal untuk setiap orang berbeda-beda, tergantung pada saat kapan mengukur denyut nadi [5].

\section{Penilaian Beban Kerja Fisik}

Menurut [6] bahwa penilaian beban kerja dapat dilakukan dengan dua metode secara objektif, yaitu metode penilaian langsung dan metode penilaian tidak langsung. Metode pengukuran langsung yaitu dengan mengukur energi yang dikeluarkan melalui asupan oksigen selama bekerja. Metode penilaian tidak langsung adalah dengan menghitung denyut nadi selama bekerja.

\section{Standar Iklim Kerja Panas}

Standar iklim kerja panas di Indonesia ditetapkan berdasarkan [7] tentang nilai ambang batas faktor fisika dan faktor kimia di tempat kerja.

Adapun tabel tentang nilai ambang batas faktor fisika dan faktor kimia di tempat kerja yaitu sebagai berikut : (lihat Tabel 1).

Tabel 1. Nilai Ambang Batas Faktor Fisika dan Kimia Di Tempat Kerja

\begin{tabular}{|c|c|c|c|}
\hline \multirow{2}{*}{$\begin{array}{c}\text { Pengaturan waktu } \\
\text { kerja setiap jam }\end{array}$} & \multicolumn{3}{|c|}{ ISBB $\left({ }^{\circ} \mathrm{C}\right)$} \\
\cline { 2 - 4 } & Beban Kerja \\
\cline { 2 - 4 } & Ringan & Sedang & Berat \\
\hline $75-100 \%$ & 31,0 & 28,0 & - \\
\hline $50-75 \%$ & 31,0 & 29,0 & 27,5 \\
\hline $25-50 \%$ & 32,0 & 30,0 & 29,0 \\
\hline $0-25 \%$ & 32,0 & 31,1 & 30,5 \\
\hline
\end{tabular}

\section{Wet Bulb Globe Temperatur (WBGT)}

Menurut [8] tahun 1957 Yaglou dan Minard menciptakan Wet Bulb Globe Temperature (WBGT) sebagai sebuah indeks untuk mengevaluasi sensasi panas dan tekanan panas selama latihan. Wet Bulb Globe Temperature (WBGT) adalah sebuah model yang digunakan untuk memperkirakan efek suhu udara, kelembaban udara, kecepatan angin, dan radiasi matahari terhadap manusia.

\section{Metodelogi Penelitian}

Adapun skema yang dilakukan dalam melakukan penelitian yaitu sebagai berikut: (lihat Gambar 1). 


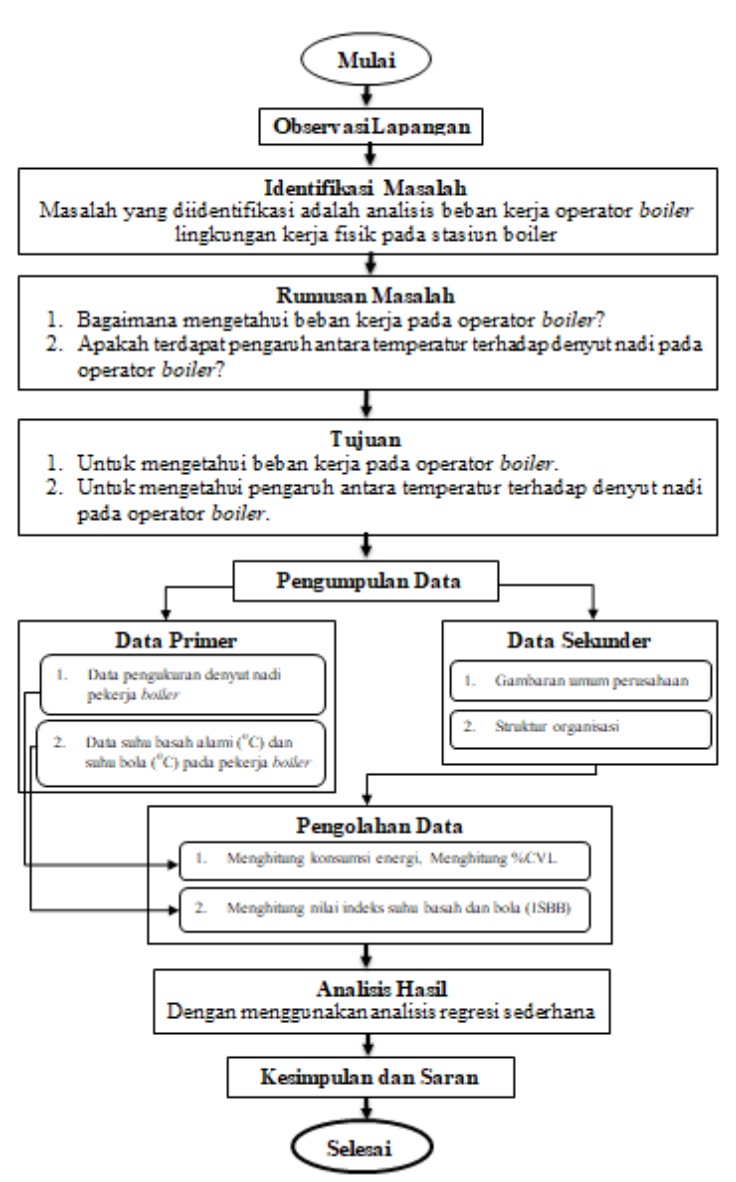

Gambar 1. Skema Metodelogi Penelitian

\section{Hasil dan Pembahasan}

\section{Pengumpulan Data}

Data tingkat aktivitas yang akan dikumpulkan dan diolah pada penelitian ini adalah data denyut nadi. Data denyut nadi digunakan untuk penilaian secara langsung menentukan jumlah kebutuhan energi yang dikonsumsi untuk suatu pekerjaan seperti pada Tabel 2 dibawah ini:

Tabel 2. Data Denyut Nadi Pekerja Boiler

\begin{tabular}{|c|c|c|c|c|c|c|}
\hline \multirow{2}{*}{ No. } & \multirow{2}{*}{ Operator } & \multirow{2}{*}{$\begin{array}{c}\text { Jenis } \\
\text { Kelamin }\end{array}$} & \multirow{2}{*}{$\begin{array}{c}\text { Umur } \\
\text { (Tahun) }\end{array}$} & \multicolumn{3}{|c|}{$\begin{array}{c}\text { Denyut Nadi } \\
\text { (denyut/menit) }\end{array}$} \\
\cline { 5 - 8 } & & & & DNI & DNK & DN Max. \\
\hline 1 & 1 & $\mathrm{~L}$ & 49 & 88 & 146 & 171 \\
\hline 2 & 2 & $\mathrm{~L}$ & 45 & 85 & 140 & 175 \\
\hline 3 & 3 & $\mathrm{~L}$ & 35 & 80 & 139 & 185 \\
\hline
\end{tabular}

Pengukuran temperatur pada lingkungan stasiun boiler dilakukan dengan 7 hari pada tiga kali pengukuran. Berikut hasil pengukuran data lingkungan kerja fisik di bagian stasiun boiler seperti pada Tabel 3 dibawah ini:

Tabel 3. Hasil Pengukuran Data Lingkungan Kerja di Bagian Boiler

\begin{tabular}{|c|c|c|c|c|c|c|}
\hline \multirow{3}{*}{ Hari } & \multicolumn{3}{|c|}{ Suhu Basah alami $\left({ }^{\circ} \mathrm{C}\right)$} & \multicolumn{3}{|c|}{ Suhu Bola $\left({ }^{\circ} \mathrm{C}\right)$} \\
\hline & \multicolumn{6}{|c|}{ Waktu } \\
\hline & 09.00 & 12.00 & 15.00 & 09.00 & 12.00 & 15.00 \\
\hline 1 & 29.7 & 29.4 & 29.3 & 39.8 & 40.6 & 40.6 \\
\hline 2 & 29.9 & 29.7 & 29.7 & 40.3 & 40.8 & 40.7 \\
\hline 3 & 30.6 & 30.6 & 30.3 & 40.8 & 41.1 & 40.9 \\
\hline 4 & 30.8 & 30.9 & 30.7 & 40.9 & 41.5 & 40.7 \\
\hline 5 & 31.4 & 31.2 & 30.9 & 41.3 & 42.1 & 41.7 \\
\hline 6 & 30.5 & 30.1 & 29.7 & 41.3 & 41.5 & 41.5 \\
\hline 7 & 30.1 & 30.2 & 29.8 & 40.8 & 40.9 & 40.5 \\
\hline Rata-rata & 30.4 & 30.3 & 30.1 & 40.7 & 41.2 & 40.9 \\
\hline
\end{tabular}

\section{Pengolahan Data}

Berdasarkan data yang telah didapatkan daripada pengumpulan data diatas, maka dilakukan pengolahan data yaitu sebagai berikut :

Perhitungan konsumsi energi untuk tenaga kerja pada stasiun boiler adalah sebagai berikut:

$$
Y=1,80411-0,0229038(X)+4,71733 \times 10^{-4}(X)^{2}
$$

Dengan $X$ : Denyut nadi kerja operator

Berikut adalah perhitungan konsumsi energi untuk tiap operator boiler dapat dilihat pada Tabel 4 sebagai berikut:

Tabel 4. Konsumsi Energi Operator Boiler

\begin{tabular}{|c|c|c|c|c|c|}
\hline No. & Operator & $\begin{array}{c}\text { Umur } \\
\text { (Tahun) }\end{array}$ & DNK & $\begin{array}{c}\text { E } \\
\text { (Kkal/menit) }\end{array}$ & $\begin{array}{c}\text { Kategori } \\
\text { Beban } \\
\text { Kerja }\end{array}$ \\
\hline 1 & 1 & 49 & 146 & 8,515 & Berat \\
\hline 2 & 2 & 45 & 140 & 7,843 & Berat \\
\hline 3 & 3 & 35 & 139 & 7,734 & Berat \\
\hline \multicolumn{4}{|c|}{ Rata-rata } & 8,031 & Berat \\
\hline
\end{tabular}

Berikut adalah hasil perhitungan \%CVL dengan klasifikasi beban kerja untuk masing-masing operator di boiler dapat dilihat pada Tabel 5 sebagai berikut:

Tabel 5. Hasil Perhitungan \%CVL dengan Klasifikasi Beban Kerja Operator Boiler

\begin{tabular}{|c|c|c|}
\hline Pekerja & \% CVL & Kategori \\
\hline 1 & 69,88 & Kerja Dalam Waktu Singkat \\
\hline 2 & 61,11 & Kerja Dalam Waktu Singkat \\
\hline 3 & 56,19 & Diperlukan Perbaikan \\
\hline Rata-rata & $\mathbf{6 2 , 3 9}$ & Kerja Dalam Waktu Singkat \\
\hline
\end{tabular}

Perhitungan ISBB pada stasiun boiler dilakukan dengan ruangan tanpa radiasi, karena berada pada ruangan tertutup tanpa radiasi dari matahari. Berdasarkan data diatas maka dihitung nilai ISBB dengan persamaan:

ISBB $=0,7$ Suhu basah alami $+0,3$ Suhu bola

ISBB $=0,7 \times 30,4+0,3 \times 40,7=33,5^{\circ} \mathrm{C}$

Dengan perhitungan yang sama seperti diatas dapat diperoleh nilai ISBB, seperti pada Tabel 6 dibawah ini: 
Tabel 6. Rekapitulasi Nilai ISBB

\begin{tabular}{|c|c|c|c|}
\hline Waktu & $\begin{array}{c}\text { Suhu Basah } \\
\text { Alami }\left({ }^{\circ} \mathbf{C}\right)\end{array}$ & $\begin{array}{c}\text { Suhu Bola } \\
\left({ }^{\circ} \mathbf{C}\right)\end{array}$ & ISBB $\left({ }^{\circ} \mathbf{C}\right)$ \\
\hline $\mathbf{0 9 . 0 0}$ & 30.4 & 40.7 & 33.5 \\
\hline $\mathbf{1 2 . 0 0}$ & 30.3 & 41.2 & 33.6 \\
\hline $\mathbf{1 5 . 0 0}$ & 30.1 & 40.9 & 33.3 \\
\hline Rata-rata & $\mathbf{3 0 . 3}$ & $\mathbf{4 0 . 9}$ & $\mathbf{3 3 . 5}$ \\
\hline
\end{tabular}

Analisis dan Perhitungan Terhadap Konsumsi Energi

Dari hasil pengolahan data, analisis yang dilakukan pada tingkat aktivitas adalah untuk melihat pengaruh denyut nadi kerja terhadap konsumsi energi operator boiler. Hal ini dapat diketahui dengan melakukan perhitungan menggunakan analisis regresi sederhana didapat persamaan yang dapat dilihat pada Tabel 7 sebagai berikut:

Tabel 7. Hasil Persamaan Denyut Nadi Terhadap Konsumsi Energi Operator Boiler

\begin{tabular}{|c|c|r|}
\hline \multicolumn{3}{|c|}{ Persamaan Regresi dan Korelasi } \\
\hline Persamaan & $\mathbf{R}$ & Keterangan \\
\hline $\mathrm{Y}=0,112 \mathrm{x}-7,8$ & 1,000 & Sangat Kuat \\
\hline
\end{tabular}

Berdasarkan perhitungan dengan menggunakan software SPSS, persamaan regresi antara denyut nadi kerja dan konsumsi energi diperoleh nilai korelasi 1,000.

Hal ini menunjukkan bahwa denyut nadi kerja mempunyai hubungan yang sangat kuat antara denyut nadi kerja dengan konsumsi energi. Semakin besar denyut nadi kerja maka konsumsi energi juga akan semakin besar.

\section{Analisis Nilai Indeks Suhu Basah dan Bola (ISBB)}

Berdasarkan perhitungan nilai Indeks Suhu Basah dan Bola (ISBB) diperoleh nilai rata-rata sebesar $33,5^{\circ} \mathrm{C}$. Hal ini menunjukkan bahwa iklim kerja di stasiun boiler melebihi NAB yang ditetapkan SNI 16-7063-2004. Untuk beban kerja berat dengan waktu kerja $83 \%$ nilai ISBB yang diperbolehkan adalah $<27,5^{\circ} \mathrm{C}$.

Kemudian dihitung nilai korelasinya untuk mengetahui pengaruh nilai Indeks Suhu Basah dan Bola (ISBB) terhadap denyut nadi operator boiler, seperti yang terlihat pada Tabel 8 dibawah ini:

Tabel 8. Hasil Korelasi Temperatur Terhadap Denyut Nadi Operator Boiler

\begin{tabular}{|c|c|}
\hline \multicolumn{2}{|c|}{ Nilai Korelasi Ganda } \\
\hline $\mathbf{R}$ & Keterangan \\
\hline 1,000 & Sangat Kuat \\
\hline
\end{tabular}

Berdasarkan perhitungan dengan menggunakan software SPSS antara denyut nadi kerja dan temperatur diperoleh nilai korelasi ganda 1,000. Hal ini menunjukkan bahwa temperatur mempunyai hubungan yang sangat kuat dengat denyut nadi kerja. Semakin tinggi temperatur maka denyut nadi juga akan semakin cepat.

\section{Kesimpulan}

Adapun kesimpulan yang didapatkan daripada penelitian yang dilakukan yaitu sebagai berikut :

1. Beban kerja yang diperoleh dari perhitungan komsumsi energi didapat hasil nilai rata-rata $E=8,031$ $\mathrm{kkal} / \mathrm{menit}$ dan nilai rata-rata $\% \mathrm{CVL}=60,39$ (kerja dalam waktu singkat) dikategorikan bahwa beban kerja operator merupakan beban kerja berat yang berarti operator tidak diperbolehkan beraktivitas dalam waktu yang lama. Dan temperatur yang diperoleh dari perhitungan rata-rata nilai ISBB pada stasiun boiler adalah $33,5^{\circ} \mathrm{C}$. Hal ini menunjukkan bahwa iklim kerja di stasiun boiler melebihi NAB yang untuk beban kerja berat nilai ISBB yang diperbolehkan adalah $<27,5^{\circ} \mathrm{C}$.

2. Temperatur pada lingkungan kerja merupakan salah satu penyebab terjadinya kelelahan operator boiler saat bekerja. Berdasarkan persamaan regresi antara denyut nadi kerja dan temperatur diperoleh nilai korelasi 1,000. Hal ini menunjukkan bahwa denyut nadi kerja mempunyai hubungan antara denyut nadi kerja dengan temperatur. Semakin tinggi temperatur maka denyut nadi juga akan semakin cepat.

\section{Daftar Pustaka}

[1] Sritomo. 2006. Ergonomi Studi Gerak dan Waktu. Surabaya: Guna Widya.

[2] Iridiastadi dan Yasserli. 2014. Ergonomi Suatu Penghantar. Bandung: PT Remaja Rosdakarya.

[3] Tarwaka, dkk. 2004. Ergonomi untuk Keselamatan, Kesehatan Kerja dan Produktivitas. Surakarta: UNIBA Press.

[4] Sedarmayanti. 2001. Manajemen Perkantoran Suatu Pengantar. Bandung: Mandar Maju.

[5] Brahmapurkar KP, Khan QH, Zodpey S, Ruikar MM, Brahmapurkar VK. Death And Defaulted Trends Among Registered TB Cases At Jagdalpur TU In Bastar District Of Chattisgarh, India. Int J Med Sci Public health. 2012; 5(11):2361-2365.

[6] Astrand, P.O dan Rodahl, K. 1977. Textbook of Work Physiology-Physiological Bases of Exercise 2nd edt. McGraw-Hill Book Company. USA

[7] Peraturan Menteri Tenaga Kerjadan Transmigrasi RI No.PER.13/MEN/ X/2011 Diaskes pada tanggal 30 Juli 2019

[8] Mochida T, Kuwabara K, dan Sakoi T. 2007. Derivation and analysis of the indoor Wet Bulb Globe Temperature index (WBGT) with a human thermal engineering approach-Part 1. Properties of the WBGT formula for indoor conditions with no solar radiation.Proceedings of Clima 2007 WellBeing Indoors. Japan: 1-8. 